\title{
Towards a theory of conscientious corporate brand co-creation: the next key challenge in brand management
}

\author{
Oriol Iglesias ${ }^{1} \cdot$ Nicholas Ind $^{2}$
}

Revised: 24 July 2020 / Published online: 2 September 2020

() Springer Nature Limited 2020

\begin{abstract}
In this article we chart the evolution of corporate brand management from an organization-centric view based on control to one rooted in a participative cocreated perspective where multiple stakeholders help to build and enrich the brand. This shift challenges many of the traditional models of corporate brand management and recognizes the importance of meeting the needs and desires of stakeholders through the adoption of a conscientious approach built on responsibility and a commitment to fairness. We illustrate our argument with such examples as Danone, SAP, Tata, Unilever and Patagonia and conclude with a research agenda to explore further the nascent field of conscientious corporate brands.
\end{abstract}

Keywords Corporate brands $\cdot$ Conscientious brands $\cdot$ Co-creation $\cdot$ Stakeholder perspective $\cdot$ Brand purpose

\section{The evolution of the brand management academic field}

Academics first became interested in the brand construct in the early 1900s (Stern 2006), when they realized that brands were identifiers, that could help build recognition and link a product to its manufacturer (Merz et al. 2009), thereby potentially influencing consumer preference. This led to a growing body of research that aimed to understand the impact of branded goods versus unbranded goods in consumer decision-making processes (i.e. Copeland 1923).

Researchers also soon realized that brands could generate positive perceptions and improve the firm's competitive advantage (Welcker 1949). Not surprisingly, this realization spurred much research on how to create a strong and favourable brand image (i.e. Gardner and Levy 1955). Academics suggested that the key was to generate functional-benefit associations, related to the utilitarian needs of customers (de Chernatony and McWilliam 1989), such as product quality

Oriol Iglesias

oriol.iglesias@esade.edu

Nicholas Ind

NicholasJonathan.Ind@kristiania.no

1 Universitat Ramon Llull, ESADE, Av. Torre Blanca, 59, 08172 Sant Cugat del Valles, Barcelona, Spain

2 Kristiania University College, Kirkegata 24-26, 0153 Oslo, Norway
(Dawar and Parker 1994). However, once the market became more crowded, and functional benefits were not enough to provide a relevant source of differentiation, scholars realized that brands should also promise symbolic benefits to customers (Park et al. 1986). Symbolic benefits are the meanings that the brand provides to customers (Levy 1959) connected to their ego, self-enhancement and position within a community (Park et al. 1986).

Overall, the foundational branding literature focuses on product brands, conceiving them as a set of perceptions grounded in functional and emotional benefits (de Chernatony et al. 2006), that allow product differentiation (i.e. Aaker 1996) and the simplification of consumer choices (Jacoby et al. 1977). From this perspective, the obvious recommendation to managers is to allocate most resources to communication activities (Di Mingo 1988) that can reinforce the brand's external image (Morrison and Crane 2007).

However, the growing importance of the service sector in developed economies fostered the emergence of services branding literature in the 1990s and 2000s. According to this stream of thinking, customer interactions with company employees, and the overall experience, largely determine the brand building process (e.g. Berry 2000; Gronroos 2006; Brakus et al. 2009). This emphasizes the key role of frontline employees (Harris and de Chernatony 2001). From this perspective, managers should broaden their scope beyond communication strategy to give more emphasis to the design and management of the overall experience (Frow and Payne 
2007; Iglesias and Bonet 2012). Only when a brand fulfils its promise and offers a consistent brand experience across all touchpoints is it capable of emotionally engaging its customers (Brodie et al. 2009). This perspective is a paradigm shift that underscores the need to build and nurture long-term relationships between the brand and its customers (Fournier 1998; Merz et al. 2009) and to develop a broader stakeholder view, which recognizes the central role of employees and of promoting a supportive corporate culture (Ind 2007).

Parallel to the development of the service branding literature, the corporate branding literature has also been gaining in relevance (e.g. Balmer 1995; Ind 1997; Harris and de Chernatony 2001; « and Schultz 2001). Corporate brands, when compared to product and services brands, encompass a broader scope and are more strategic (Roper and Davies 2007). More precisely, they aim at promoting long-term relationships between an organization and its diverse stakeholders (de Chernatony 2002), which include clients, employees, suppliers, shareholders, commercial partners and citizens (Davies et al. 2010). In essence, 'the core of a corporate brand is an explicit covenant between an organization and its key stakeholder groups' (Balmer and Gray 2003, p. 982).

Interestingly, the foundational corporate brand management literature seems to suggest that managers unilaterally define this covenant and that they mostly build corporate brands from an inside-out and top-down approach (Iglesias et al. 2020a). For instance, the traditional literature defines corporate brand identity as a unique set of stable values determined by managers to illustrate what the corporate brand stands for, and what makes it unique (Keller 1993; Aaker 1996; de Chernatony 1996). From this perspective, corporate brands are managerial creations and managers should act as brand custodians (Kapferer 2012).

\section{Towards corporate brand co-creation}

The emergence of the Internet, online communities and social media have challenged traditional corporate brand management approaches (Gyrd-Jones et al. 2013), which were largely grounded in the assumption of managerial control. Instead, in the current hyper-connected digital environment, the brand building process has moved beyond the control of the organization and its managers (Iglesias and Bonet 2012; Iglesias et al. 2013)—witness, for example, the growing relevance of naturally occurring online brand communities in the development of brand meaning (Cova et al. 2011; Muniz and O'Guinn 2001). This suggests that corporate brands are organic entities (Iglesias et al. 2013), which continuously evolve and develop through a symbiotic relationship between the organization and its stakeholders. In this view, corporate brands are fluid and unstable, as brand meanings are 'always in circulation and flux' (Batey
2008, p. 104), often in ways neither planned nor desired by brand managers (Iglesias et al. 2013). This makes the idea of managerial control an illusion. Now, managers can only seek to influence a corporate brand's stakeholders (Iglesias and Bonet 2012), which in turn makes the distinction between the internal and external locus of corporate brand building redundant (Black and Veloutsou 2017; von Wallpach et al. $2017 \mathrm{a}, \mathrm{b})$. Indeed, the boundaries of the organization itself become blurred as internal and external stakeholders join together in the co-creation of brand meaning (Kornberger 2010).

In essence, corporate brands are co-created organically, together with multiple stakeholders (e.g. Vallaster and von Wallpach 2013; von Wallpach et al. 2017a; Iglesias et al.; 2013; 2020a; da Silveira et al. 2013; Kornum et al. 2017). This is a continuous value creation process 'that unfolds over time through a series of interactions that take place between multiple internal and external stakeholders' (Iglesias et al. 2020a, p. 33) as they contest, discuss, negotiate and reinterpret a brand's meanings (Iglesias and Bonet 2012; Vallaster and von Wallpach 2013). According to Iglesias et al. (2020a, p. 32), the core of a corporate brand, its identity, is co-created in 'an ongoing dynamic process where multiple internal and external stakeholders engage in four different but interrelated performances: communicating; internalizing; contesting; and elucidating'. Communicating involves the activities performed by stakeholders in transmitting the corporate brand identity; internalizing concerns the activities performed to bring the brand identity to life; contesting is a comparative process by which stakeholders confront the corporate brand identity with their perceptions; elucidating involves activities performed by stakeholders to develop an evolved shared understanding of the corporate brand.

The co-creation paradigm acknowledges the paramount importance of the myriad interactions that the corporate brand's stakeholders establish among them (Kristal et al. 2020) and which represent the key building blocks of the corporate brand. However, for these interactions to build a strong corporate brand, they need to be rooted in trusting relationships, fairness and reciprocity (Ind and Ryder 2011). This highlights the relevance of empowering different stakeholders (Kennedy and Guzman 2017) and demands a new leadership style that needs to be much more participatory, humble and empathetic (Iglesias et al. 2013). Leaders also need to promote an open organizational mindset that sees all stakeholders as relevant potential collaborators (Ind et al. 2017), so that they can orchestrate a strategic collaborative innovation network (Libert and Fenley 2015), capable of fostering competitive advantage.

The challenge for managers is how to reconcile their desire to preserve the essence of the corporate brand, its heritage and core values, (Balmer and Burghausen 2015; Urde and Greyser 2007) with the need to embrace stakeholders' 
feedback, proposals and actions (Kristal et al. 2020). This underlying permanent tension requires more flexible corporate brand propositions than the traditional corporate brand covenant or the classical corporate brand identity models (Keller 1993; Aaker 1996, de Chernatony 1996; Balmer and Soenen 1999). Instead, corporate brands need a purpose (Gyrd-Jones 2012), which has the primary role of expressing the raison d'être of the brand. A purpose allows an organization to 'make a positive, transformative impact on the world' (Iglesias and Ind 2016, p. 206), while building a profitable business. In other words, a purpose is concerned with the way in which a corporate brand creates value for all its diverse stakeholders. It should both provide clarity so that managers can use it as a filter for strategic decision-making, and be dynamic, in that it can inspire and engage different stakeholders to further develop and elucidate a shared and evolving understanding of the corporate brand (Iglesias et al. 2020a). Surprisingly, there is a gap between the managerial discussions around purpose, which have become mainstream, and academia, where there is an inexplicable lack of research on how corporate brands should build a purpose and what the benefits of doing so are (Golob et al. 2020). The focus on purpose also implies a new model of brand governance (Hatch and Schultz 2010). Rather than managers seeing themselves as brand custodians, who rigidly try to preserve the integrity of the corporate brand, they should see themselves as 'conductors' (Michel 2017) who allow the corporate brand to adapt to the needs of multiple stakeholders, while being true to its purpose, and appreciating and celebrating history and heritage (Iglesias et al. 2020c).

However, even if the co-creative approach to corporate branding signifies a relevant paradigm shift in brand management, it is still a nascent field of study and demands many more empirical studies, and further theoretical development. More precisely, most of the research in the area has been conducted in $\mathrm{B} 2 \mathrm{C}$ contexts (e.g. Vallaster and von Wallpach 2013; Gyrd-Jones and Kornum 2013; Black and Veloutsou 2017). There is still scarce empirical research in the B2B domain, even though interactions and networks represent the very essence of B2B organizations (Mäläskä et al. 2011; Törmälä and Gyrd-Jones 2017, Koporcic and Halinen 2018; Iglesias et al. 2020a; Kristal et al. 2020). Additionally, more research is needed in the flourishing B2B2C arena (Mingione and Leoni 2019). In parallel, there is a need for empirical studies with a more balanced perspective of different stakeholders (von Wallpach et al. 2017a), as most of the studies either focus on customers, or do not take into account all the relevant internal and external stakeholders (Iglesias et al. 2020a). Finally, more research is needed that adheres to a performative perspective that derives from Goffman $(1959,1967)$, which suggests that if corporate brands are co-created in a continuous process, research should focus on understanding stakeholders' performances in the co-creation of corporate brands (da Silveira et al. 2013; von Wallpach et al. 2017b; Iglesias et al. 2020a).

\section{Conscientious corporate brands}

The twenty-first century has seen the emergence of an extraordinarily volatile, uncertain, complex and ambiguous (VUCA) world (Bennett and Lemoine 2014). Humanity faces significant challenges, such as climate change, increasing inequalities among countries and within societies, and the potential impact of new technologies, including robotization in the labour market. Additionally, the COVID-19 crisis has accentuated these challenges and put more pressure on corporate brands to acknowledge their broader responsibilities and embrace a more conscientious approach to management.

In parallel, consumers are becoming more conscious about this emergent reality and research shows the rise of ethical consumerism (Carrigan and Attalla 2001; Shaw and Shiu 2002), as a mainstream rather than a fringe phenomenon (Carrington et al. 2014; Caruana et al. 2016). Even if, there is still a notable gap between ethical intentions and actual behaviour (Govind et al. 2019), mainstream consumers increasingly take into consideration the impact of their consumption choices upon society and the environment (Shaw and Shiu 2002; Caruana et al. 2016).

During the last two decades, many brands have met these challenges through Corporate Social Responsibility (CSR) programmes. Undoubtedly, CSR has helped brands to develop a more conscientious approach to business (Golob and Podnar 2019), while also generating relevant competitive benefits, such as higher levels of customer loyalty (e.g. Lee et al. 2012), stronger brand equity (e.g. Hur et al. 2014) and higher levels of employee commitment (e.g. Skudiene and Auruskeviciene 2012). However, at the same time, too many organizations have adopted CSR as a passive reaction to external stakeholder pressure to behave in a socially responsible manner and to reduce negative impacts, or as a mechanism to manage and reduce potential risks (Walsh and Beatty 2007). This has raised significant questions as to the legitimacy of CSR practice. Indeed, some organizations are guilty of sins of omission: saying one thing in the public arena, while doing another thing in secret (Lyon et al. 2018). Others have used CSR as a way to burnish their corporate reputations, without integrating it in their identity and business processes (Maxfield 2008; Pope and Wæraas 2016). This has led to concerns about the corporate motivations and ethics behind CSR investments (Joyner and Payne 2002), and the belief that CSR practices are insincere and manipulative (Maxfield 2008; Pope and Wæraas 2016). Additionally, 
CSR has in most cases failed to properly deal with three key challenges that are spurring emerging discussions in the marketing, brand management and ethics literature.

First, most of the key challenges that humanity is facing are a combination of social, economic, governance and even health issues, which can only be tackled by adopting a stakeholder approach. However, even if there have been claims in the branding literature for a wider stakeholder perspective (e.g. Balmer et al. 2011), empirical research shows that most business organizations have still not embraced a stakeholder view and still see their shareholders as the key stakeholder (Jurgens et al. 2010). The idea behind the primacy of the shareholder was presented by Milton Friedman (1970) in his influential article in The New York Times and later on supported by agency theory (Jensen and Meckling 1976). These views have influenced how organizations and brands are managed and encouraged a short-term perspective (Lodish and Mela 2007). However, recently, new streams of thought have started to flourish in both academia and management practice, that advocate a more balanced stakeholder perspective (Freeman et al. 2007; Smith and Rönnegard 2016), rooted in fairness and conscientiousness (Ind and Horlings 2016). According to Golob et al. (2020, p. 125) 'by addressing issues that matter to different stakeholders and people in general and which have the potential to change their daily lives, brand management research would be able to position itself more at the forefront of contemporary pressing problems faced by our global society'. This more balanced stakeholder perspective demands the prevalence of longterm thinking, which runs counter to the sometimes shortterm view of shareholders (Ind and Ryder 2011).

Second, most organizations have still not developed adequate measures to understand the value that their CSR activities provide to their different stakeholders (Knox and Maklan 2004). To serve their diverse stakeholders, appropriately and authentically, corporate brands need to rethink how they measure value, beyond the purely financial. Surprisingly, even if there is significant discussion in the brand management literature regarding how value is co-created by diverse stakeholders (e.g. Iglesias et al. 2013, Ramaswamy and Ozcan 2014), there is still scarce research as to what value means to each stakeholder and how to measure it beyond a financial approach (Harrison and Wicks 2013). A promising stream of research here is the Sustainable Balanced Scorecard (SBSC), which aims to balance financial and non-financial performance measures, by explicitly recognizing environmental, social and ethical performance metrics (Hansen and Schaltegger 2017). However, more research is needed to better comprehend under which circumstances and conditions the SBSC can be used successfully (Hristov et al. 2019). Additionally, it is also essential to study how to integrate the SBSC within the corporate brand strategy formulation and implementation process, as 'the function of an SBSC is to support strategy implementation' (Hansen and Schaltegger 2018, p. 938).

Third, CSR is often tangential to the business, rather than embedded in its core. This disconnection between CSR activities and strategic goals (Maon et al. 2017) leads to stakeholders seeing CSR activities as less authentic (Mazutis and Slawinski 2015). According to Golob and Podnar (2019), there are three views on integrating CSR into brand strategy. First, many brands simply do not see CSR as part of their brand positioning. Second, some others view CSR as a supplement to the brand positioning. A third group, which comprises a minority of brands, strategically place CSR at the core of their brand positioning and consider it as a key brand ingredient (Kitchin 2003; van Rekom et al. 2013). Consequently, most corporate brands still need to figure out how to embed CSR at the core of their brand strategy and to serve authentically their different stakeholders with a balanced perspective. This also reinforces the need to define and embrace a corporate brand purpose.

All in all, corporate brands face an unprecedented VUCA environment with growing pressures to develop new management approaches capable of giving a holistic response to the expectations of diverse stakeholder groups, and of creating value beyond the purely financial (Iglesias et al. 2020b; Jurgens et al. 2010; Smith and Rönnegard 2016). This suggests the relevance of a strategic approach to CSR. However, failings in the practice of CSR and growing stakeholder expectations of business to tackle pressing existential problems suggest going beyond CSR. This is the rationale behind conscientious brands (Ind and Ryder 2011; Ind and Horlings 2016) and the idea that 'conscience' should be at the core of the corporate brand identity. A brand with a conscience indicates both a truth to self and a commitment to social responsibility and fairness. Further, it suggests an openness to dialogue and a willingness to submit decisions to public scrutiny. It is dynamic in the sense that it should drive strategic decisions, including the corporate brand positioning and the value proposition, and the relationships the corporate brand has with different stakeholders. This conscience should ensure that CSR is not a department, but rather integrated into the corporate culture. This is the thinking behind what we call conscientious corporate brands.

Conscientious corporate brands define and embrace a transformative purpose and a set of guiding principles which are rooted in their heritage (Iglesias et al. 2020c) and the organization's distinctive capabilities (Iglesias and Ind 2016). A strong ethical identity should be embedded in the business strategy, but also in operations and relationships (Rindell et al. 2011). To achieve this, the purpose and principles need to be lived by the corporate brand's employees, but ideally also adopted by its other stakeholders as well. This reinforces the need to develop a supportive corporate culture (Hatch and Schultz 2008), which can nurture the corporate 
brand purpose across stakeholder interactions and to foster clear policies and practices, that align with the purpose and identity in recruiting, promoting, training, evaluating and compensating employees (Iglesias and Saleem 2015). When a corporate brand has a solid purpose and guiding principles, decisions can be taken with agility (Hatch and Schultz 2008), which is a key advantage in the current VUCA environment. Take for example, Patagonia, the American outdoor sports clothing company, which has long been lauded for its commitment to its environmentally focused purpose and its principles, such as quality and integrity. At the onset of the COVID-19 crisis, Patagonia moved quickly to close all its 39 stores in the USA and ecommerce business, while taking actions to meet the needs of employees, communities and citizens, that align with its beliefs as a B Corporation. B Corporations are certified companies that balance purpose and profit, and that are required to consider the impact of their decisions on their different stakeholders, including their employees, customers, suppliers, the community and the environment (Kim et al. 2016; Temple-West 2020). Similarly, the German software company, SAP, which has a stated purpose to 'help the world run better and to improve people's lives', has been able to adapt rapidly to meet people's needs. As an illustration of this, during the onset of the crisis, SAP developed a cloud-based application for the City of Hamburg and its development bank, to enable the rapid and secure disbursal of funds to small businesses and the self-employed. Within hours of making the application available, 38,000 users had registered and more than 16,000 applications been made.

Conscientious corporate brands adopt and promote an authentic stakeholder perspective, which allows them to balance value creation for their different stakeholders (Iglesias and Ind 2016). This is about understanding and embracing the broader responsibilities that corporate brands have, beyond serving their clients and shareholders, by taking into consideration the needs and expectations of their employees, their partners and society (Iglesias et al. 2020b). Additionally, conscientious corporate brands consider the Earth as another key stakeholder that they need to preserve and serve. This authentic stakeholder perspective implies not only taking into consideration the different corporate brand's stakeholders, but also offering them the opportunity to co-create the organization's social and environmental strategic agenda (Edinger-Schons et al. 2020). Promoting this balanced stakeholder perspective demands using the corporate brand purpose and principles as a lens to make difficult choices when tensions arise due to conflicting interests among stakeholders. For example, during the COVID-19 crisis many organizations were confronted with the dilemma of paying dividends to their shareholders or safeguarding the jobs of their employees and partners. Resolving such a dilemma requires a humanistic approach to management, which is rooted in fairness (Iglesias and Ind 2016). Dilmah Tea demonstrates this humanistic mindset in the way it meets the needs of its stakeholders. The premium ethical tea brand, where employees pick leaves in the traditional manual manner, pays fair wages to collectors so that they enjoy life and prosper, instead of enriching the company at the expense of the pickers. The ultimate objective is to create value and to distribute it among the corporate brand's stakeholders in a fair way, contributing also to the development of Sri Lankan society. In the words of the Dilmah Tea corporate brand, 'Business is a matter of human service' (Yan 2016).

Another notable attribute of Dilmah Teas and many conscientious corporate brands is a long-term orientation. This is a result of the strong connection to different stakeholders and the sense such brands have of being embedded in a community, which can be either based on shared interest (for example, Patagonia) or geography (for example, Dilmah). An oft-levelled criticism of shareholder-focused companies is their focus on quarterly reporting and short-termist thinking (Lodish and Mela 2007). Companies such as Dilmah, Patagonia (who talk of thinking 100 years ahead), DNV GL and Tata Steel have the advantage of either private ownership or ownership through foundations. For example, while the holding company of Tata Steel is public, the Tata Trusts own $66 \%$ of the group equity. Perhaps, not surprisingly, Tata Steel, which dates back to 1907, is fully integrated into its community. Indeed, it founded the city of Jamshedpur in India and still runs this million plus population city to this day. The founder of Tata, Jamsetji Tata, noted 'In a free enterprise, the community is not just another stakeholder in business, but in fact the very purpose of its existence' (Horo and Vasudevan 2016, p. 159).

While public companies perhaps face pressure to perform in the short-term, they also need to think long-term about their corporate brands. When Paul Polman took over the helm of the Anglo-Dutch company, Unilever, he established a strategy known as, the Sustainable Living Plan, which had a ten-year time perspective and set out to double sales while halving environmental impacts. To tackle short-termism, he told investors they would no longer get quarterly reports nor earnings guidance. With a very specific commitment to a stakeholder view, he informed would-be investors that if they didn't buy into the brand's long-term and sustainable model, Unilever didn't want their money. For Unilever, this commitment to sustainability was not an add-on, but core to the strategy and to its operations. Polman and his managers, integrated sustainability into the way products are produced, the funding of the company (by using green bonds) and into communications that aimed to encourage consumers to alter their behaviour. This last point became fundamentally important to the ambition of the Sustainable Living Plan, as the doubling of sales impacted on environmental impacts, 
not least because around $70 \%$ of those impacts come when the consumer uses a product (Ind 2016).

\section{Co-creating conscientious corporate brands}

Co-creation is at the heart of conscientious corporate brands. This is because co-creation has the potential to balance the invisible hand of free markets with the visible and united hands of the corporate brand's diverse stakeholders (Ramaswamy and Ozcan 2014). This demands a genuine will and an absolute commitment to listening to different stakeholders' needs, expectations and desires. However, unfortunately, too many organizations are still primarily concerned with meeting the expectations of their shareholders, even if they claim to engage in a dialogue with their different stakeholders (Iglesias et al. 2020b). Instead, conscientious corporate brands promote an authentically balanced stakeholder perspective. Additionally, they are not only committed to listening to stakeholders, but most importantly, they engage them in their strategic decision-making processes. Conscientious corporate brands which adhere to this strategic view of cocreation, see their stakeholders as key strategic partners with whom they need to build long-term, trustworthy collaborative relationships. Here, stakeholders are seen as value cocreators, 'rather than as entities to be merely managed by the enterprise' (Ramaswamy and Ozcan 2014, p. 249).

As an illustration of this, Emmanuel Faber, CEO of multinational food producer, Danone noted at the height of the COVID pandemic that "we are on the threshold of a time when what we mean by "in the ordinary course of business" will change forever. This is an extraordinary moment [...] as employees, consumers, customers, partners, governments and shareholders now see the critical importance of a balanced multi-stakeholder approach to value creation and sharing' ${ }^{1}$. This statement reflects Danone's 'One person, One voice' initiative - a very ambitious and innovative governance and employee engagement model, that invited Danone's 100,000 employees worldwide to co-create Danone's 2030 strategic goals, which are grounded in the belief that the health of people and the planet are interconnected. The objective was to allow Danone's employees to co-own the company's strategic agenda and goals, both at the global and local levels, while building a healthier future for the company, its employees and communities. To increase a sense of ownership among the brand's employees, every Danone employee was given one share in combination with an annual, amplified dividend-based incentive scheme and

\footnotetext{
${ }^{1}$ https://www.globenewswire.com/news-release/2020/05/20/20361 11/0/en/Danone-to-pioneer-French-Entreprise-\%C3\%A0-Missionmodel-to-progress-stakeholder-value-creation.html.
}

the opportunity to invest in the company at a discounted price. These initiatives align with Danone's commitment to become the first listed company in France to adopt the 'Enterprise à Mission' model, which promotes the development of companies with a balanced stakeholder perspective and a transformative purpose that embraces social and environmental causes (Abboud 2020). Danone North America is already the largest B Corporation in the world and Danone has the ambition to achieve B Corporation standards globally (to date 20 of the company's subsidiaries are B Corporation certified).

This balanced stakeholder perspective is also a spur to external co-creation, whereby Danone uses what it calls, 'materiality analysis', to co-create their social, environmental and governance strategies. This methodology involves the active engagement of hundreds of Danone's employees, key customers and external stakeholders in the definition and prioritization of the goals to be achieved. The underlying reasoning is that a conscientious corporate brand cannot be constructed inside-out and top-down. Instead, conscientious corporate brands need to take into consideration different perspectives and enable co-creation by multiple internal and external stakeholders to define and prioritize social and environmental challenges. Muriel Pénicaud, Chair of the Board of the Danone Ecosystem Fund argues, 'pooling our complementary fields of expertise, traditionally confined to their respective areas of action, to find solutions to current economic, societal and environmental challenges together, is the aim of co-creation'.

The Danone case illustrates how strategic co-creation (Ind et al. 2017) can help a corporate brand to get relevant inputs from its diverse stakeholders, and to develop together with them more relevant responses to pressing societal and environmental challenges. Additionally, by embracing cocreation, conscientious corporate brands can also generate more trustworthy relationships with their stakeholders (Iglesias et al. 2020b).

However, to co-create a conscientious corporate brand, organizations face four key challenges. First, they will need to recruit, promote and foster executives capable of embracing a transformative, responsible, empathetic and participatory leadership style (Ind et al. 2013). Transformative leaders aim to balance profits and purpose and are committed to using business to foster a positive transformative change in society, the environment and the competitive landscape. Responsible leaders understand that they need to balance short-term and long-term objectives. Empathetic leaders are sensible to the expectations and demands of their diverse stakeholders and embrace a participatory leadership style

\footnotetext{
2 http://danone-iar-prod.s3.amazonaws.com/Materiality-Matrix-ENV3-2.pdf.
} 
that recognizes the value of co-creating strategies together with key stakeholders. Here, it is important to highlight the key role that business schools can play in promoting this new type of leadership and to break free from the dominant educational model of recent times.

Second, conscientious corporate brands will need to build an open and relationship-based corporate culture (Iglesias et al. 2020a). Research has shown that a resistant corporate culture is the key barrier to overcome when attempting to embrace strategic co-creation (Ind et al. 2017). Unfortunately, too many organizations believe that making strategic decisions is solely the task of internal experts, rather than a process that can benefit from the involvement of customers and other stakeholders. The internal approach to stakeholder engagement and co-creation tends to promote short-term relationships with corporate brand stakeholders. However, conscientious corporate brands understand that they need to open up and embrace the perspectives of their stakeholders, whose contributions can be extremely valuable (Kazadi et al. 2016). According to this philosophy, co-creation is a strategic asset (Ind et al. 2017) which allows brands to orchestrate a collaborative innovation network capable of developing a competitive advantage (Libert and Fenley 2015). This requires building and nurturing long-term relationships with the corporate brand's diverse stakeholders.

Third, new governance models, capable of integrating key internal and external stakeholders in strategic decision-making bodies and processes, will be required. This is extremely relevant, as unfortunately there is too often a 'disconnection of many salient stakeholders from company decisions on CSR' (Mason and Simmons 2014, p. 77). Strategic decisions are taken by the "boards of directors, as this key group defines and implements corporate strategy, and serves to safeguard the interests of key beneficiaries' (Mason and Simmons 2014, p. 77), most of whom are the shareholders of the organization. Consequently, there is an urgent requirement to conduct research as to how conscientious corporate brands and social, environmental and ethical objectives can be effectively enacted through new corporate governance models (Mason and Simmons 2014). At the same time, it is also important to understand that the involvement of stakeholders in the key governance bodies of corporate brands and organizations will demand higher levels of organizational self-disclosure (Hatch and Schultz 2010). This is about developing reporting systems capable of ensuring adequate degrees of transparency and promoting a corporate culture willing to embrace the associated risks (Hatch and Schultz 2010).

Finally, conscientious corporate brands will need to define specific key performance indicators (KPIs), which measure the performance of the corporate brand purpose, and its outcomes, from the perspective of diverse stakeholders. As discussed, the Sustainable Balanced Scorecard represents a very promising stream of research, which is embraced by managerial practice, and that aims at balancing financial and non-financial performance measures, explicitly defining environmental, social and ethical performance metrics (Hansen and Schaltegger 2017). Notably, Danone has developed a very comprehensive set of KPIs, which relate to the organization's financial and environmental, social, health and nutritional performance. The issue here is how to ensure that the definition of these KPIs it is not solely an internal process, but is co-created together with corporate brand stakeholders.

\section{Conscientious corporate brands: research agenda}

Conscientious corporate brands are a growing managerial reality, but still a nascent academic field. This indicates the need for further conceptual and empirical studies, both qualitative and quantitative, which can contribute to the development of the domain. More precisely, we believe that it is essential to conduct research on the following six topics:

First, there is the need for more research that can help to conceptualize further conscientious corporate brands and to study their antecedents and potential outcomes. Some questions are:

- What are the key characteristics of conscientious corporate brands?

- What are the antecedents of conscientious corporate brands?

- What are the outcomes that conscientious corporate brands are likely to attain?

Second, there is an urgent need to conduct academic research that can explain how conscientious corporate brands should define and promote a brand purpose. It is important to understand the potential connections between the corporate brand purpose and corporate brand heritage and capabilities. More specifically:

- How should conscientious corporate brands define and embrace a corporate brand purpose?

- Does the corporate brand purpose need to be grounded in the corporate brand's history and heritage? Does it need to be linked to the organization's capabilities?

- How can conscientious corporate brands connect corporate brand purpose to strategy?

- What key performance indicators should conscientious corporate brands develop to measure the degree of achievement of their corporate brand purpose? 
Third, it is essential to conduct empirical research to study how corporate brands can develop a balanced multi-stakeholder perspective. Some related research questions are:

- How can conscientious corporate brands foster a balanced stakeholder perspective?

- What role do different stakeholders (CEO, investors, employees, etc.) play in encouraging conscientious corporate brands?

- How can conscientious corporate brands reconcile potential conflicts of interest among their stakeholders?

Fourth, more research is needed to analyse how to embrace a long-term perspective in strategic decision-making. A few potential questions are:

- How can conscientious corporate brands promote a longterm strategic perspective in their strategic decision-making processes?

- How can conscientious corporate brands reconcile shortterm and long-term perspectives?

Fifth, we also call for research as to which type of leadership style and corporate culture, favours the development of conscientious corporate brands. More specifically:

- What type of leadership style can best promote a conscientious corporate brand?

- What type of corporate culture can best support the development of a conscientious corporate brand?

- Do conscientious corporate brands obtain any positive outputs in terms of employee engagement and/or attractiveness as an employer brand?

Finally, we urge researchers to investigate the metrics and governance models needed to promote conscientious corporate brands. Some questions are:

- What are the relevant metrics that will ensure conscientious corporate brands measure performance from all perspectives?

- Could the SBSC be a potentially relevant measurement model for conscientious corporate brands? How should the SBSC be integrated with the corporate brand strategy formulation and implementation processes?

- Which governance models could help promote a long-term and multi-stakeholder perspective?

\section{References}

Abboud, L. 2020. Danone adopts new legal status to reflect social mission. Financial Times. 26 June 2020. https://www.ft.com/ content/1eff9241-ef11-4a38-8b5c-bb825fa108ca.

Aaker, D.A. 1996. Building strong brands. New York: The Free Press.

Balmer, J.M.T. 1995. Corporate branding and connoisseurship. Journal of General Management 21 (1): 24-46.

Balmer, J.M.T., and G.B. Soenen. 1999. The ACID test of corporate identity management. Journal of Management 15: 69-92.

Balmer, J.M.T., and E.R. Gray. 2003. Corporate brands: what are they? What of them? European Journal of Marketing 37 (7/8): 972-997.

Balmer, J.M., S.M. Powell, and S.A. Greyser. 2011. Explicating ethical corporate marketing. Insights from the BP Deepwater Horizon catastrophe: The ethical brand that exploded and then imploded. Journal of Business Ethics 102 (1): 1-14.

Balmer, J.M.T., and M. Burghausen. 2015. Explicating corporate heritage, corporate heritage brands and organisational heritage. Journal of Brand Management 22 (5): 364-384.

Batey, M. 2008. Brand Meaning. New York, NY: Routledge.

Bennett, N., and G.J. Lemoine. 2014. What a difference a word makes: Understanding threats to performance in a VUCA world. Business Horizons 57 (3): 311-317.

Berry, L.L. 2000. Cultivating service brand equity. Journal of the Academy of Marketing Science 28 (1): 128-137.

Black, I., and C. Veloutsou. 2017. Working consumers: Co-creation of brand identity, consumer identity and brand community identity. Journal of Business Research 70: 416-429.

Brakus, J.J., B.H. Schmitt, and L. Zarantonello. 2009. Brand experience: What is it? How is it measured? Does it affect loyalty? Journal of Marketing 73 (3): 52-68.

Brodie, R.J., J.R.M. Whittome, and G.J. Brush. 2009. Investigating the service brand: A customer value perspective. Journal of Business Research 62: 345-355.

Carrigan, M., and A. Attalla. 2001. The myth of the ethical consumer-do ethics matter in purchase behaviour? Journal of consumer marketing 18 (7): 560-578.

Carrington, M.J., B.A. Neville, and G.J. Whitwell. 2014. Lost in translation: exploring the ethical consumer intention-behavior gap. Journal of Business Research 67 (1): 2759-2767.

Caruana, R., M.J. Carrington, and A. Chatzidakis. 2016. 'Beyond the attitude-behaviour gap: novel perspectives in consumer ethics': introduction to the thematic symposium. Journal of Business Ethics 136 (2): 215-218.

Copeland, M.T. 1923. Relation of Consumers' Buying Habits to Marketing Methods. Harvard Business Review 1 (3): 282-289.

Cova, B., D. Dalli, and D. Zwick. 2011. Critical perspectives on consumers' role as 'producers': Broadening the debate on value co-creation in marketing process. Marketing Theory 11 (3): 231-241.

da Silveira, C., C. Lages, and C. Simões. 2013. Reconceptualizing brand identity in a dynamic environment. Journal of Business Research 66 (1): 28-36.

Davies, G., R. Chun, and M.A. Kamins. 2010. Reputation gaps and the performance of service organizations. Strategic Management Journal 31 (5): 530-546.

Dawar, N., and P. Parker. 1994. Marketing universals: Consumer's use of brand name, price, physical appearance and retailer's reputation as signals of product quality. Journal of Marketing 58 (April): 81-95.

de Chernatony, L., and G. McWilliam. 1989. The Strategic Implications of Clarifying How Marketers Interpret 'Brands'. Journal of Marketing Management 5 (2): 153-171. 
de Chernatony, L. 1996. 2001-The brand management odyssey. Journal of General Management 21 (4): 15-30.

de Chernatony, L. 2002. Living the corporate brand: Brand values and brand enactment. Corporate Reputation Review 5 (2): 113.

de Chernatony, L., S. Cottoma, and M. Segal-Horn. 2006. Communication service brands' values internally and externally. The Service Industries Journal 26 (8): 819-837.

Di Mingo, E. 1988. The Fine Art of Positioning. The Journal of Business Strategy 9: 34-38. https://doi.org/10.1108/eb039211.

Edinger-Schons, L.M., L. Lengler-Graiff, S. Scheidler, G. Mende, and J. Wieseke. 2020. Listen to the voice of the customer-First steps towards stakeholder democracy. Business Ethics: An European Review 29 (3): 510-527.

Freeman, R.E., J.S. Harrison, and A.C. Wicks. 2007. Managing for stakeholders: Survival, reputation, and success. London: Yale University Press.

Friedman, M. 1970. The social responsibility of business is to increase its profits. The New York Times Magazine. September 13, 1970.

Frow, P., and A. Payne. 2007. Towards the perfect customer experience. Journal of Brand Management 15 (2): 89-101.

Fournier, S.M. 1998. Consumers and their brands: Developing relationship theory in consumer research. The Journal of Consumer Research 24 (4): 343-374. https://doi.org/10.1086/209515.

Gardner, B.B., and S.J. Levy. 1955. The product and the brand. Harvard Business Review 33: 33-39.

Goffman, E. 1959. The presentation of self. Butler, Bodies that Matter.

Goffman, E. 1967. On face-work. Interaction ritual, 5-45.

Golob, U., and K. Podnar. 2019. Researching CSR and brands in the here and now: an integrative perspective. Journal of Brand Management 26: 1-8.

Golob, U., M.A.P. Davies, J. Kernstock, and S.M. Powell. 2020. Trending topics plus future challenges and opportunities in brand management. Journal of Brand Management 27: 123-129.

Govind, R., J.J. Singh, N. Garg, et al. 2019. Not walking the walk: How dual attitudes influence behavioral outcomes in ethical consumption. Journal of Business Ethics 155: 1195-1214. https:// doi.org/10.1007/s10551-017-3545-z.

Gronroos, C. 2006. Adopting a service dominant logic for marketing. Marketing Theory 6 (3): 317-333.

Gyrd-Jones, R. 2012. Five ways branding is changing. Journal of Brand Management 20 (2): 77-79.

Gyrd-Jones, R., B. Merrilees, and D. Miller. 2013. Revisiting the complexities of corporate branding: Issues, paradoxes, solutions. Journal of Brand Management 20 (7): 571-589.

Gyrd-Jones, R., and N. Kornum. 2013. Managing the co-created brand: Value and cultural complementarity in online and offline multistakeholder ecosystems. Journal of Business Research 66 (9): 1484-1493.

Hansen, E.G., and S. Schaltegger. 2017. The sustainable balanced scorecard: A systematic review of architectures. Journal of Business Ethics 133: 193-221.

Hansen, E.G., and S. Schaltegger. 2018. Sustainability balanced scorecards and their architectures: Irrelevant or misunderstood? Journal of Business Ethics 150: 937-952.

Harris, F., and L. de Chernatony. 2001. Corporate branding and corporate brand performance. European Journal of Marketing 35 (3/4): 441-456

Harrison, J.S., and A.C. Wicks. 2013. Stakeholder theory, value, and firm performance. Business Ethics Quarterly 23 (1): 97-124.

Hatch, M.J., and M. Schultz. 2001. Are the strategic stars aligned for your corporate brand? Harvard Business Review 79 (2): 129-134.

Hatch, M.J., and M. Schultz. 2008. Taking brand initiative: How companies can align strategy, culture, and identity through corporate branding. Hoboken: Wiley.
Hatch, M.J., and M. Schultz. 2010. Toward a theory of brand co-creation with implications for brand governance. Brand Management 17 (8): 590-604.

Horo, S.J., and S. Vasudevan. 2016. Building a caring organization. In Brands with a conscience: How to build a successful and responsible brand, ed. N. Ind and S. Horlings, 158-176. London: Kogan Page.

Hur, W.M., H. Kim, and J. Woo. 2014. How CSR leads to corporate brand equity: Mediating mechanisms of corporate brand credibility and reputation. Journal of Business Ethics 125 (1): 75-86.

Hristov, I., A. Chirico, and A. Apolloni. 2019. Sustainability value creation, survival, and growth of the company: A critical perspective in the sustainability balanced scorecard (SBSC). Sustainability 11: 2-19.

Iglesias, O., and E. Bonet. 2012. Persuasive brand management: How managers can influence brand meaning when they are losing control over it. Journal of Organizational Change Management 25 (2): 251-264.

Iglesias, O., N. Ind, and M. Alfaro. 2013. The organic view of the brand: A brand value co- creation model. Journal of Brand Management 20 (8): 670-688.

Iglesias, O., and F. Saleem. 2015. How to support consumer-brand relationships: The role of corporate culture and human resource policies and practices. Marketing Intelligence and Planning 33 (2): 216-234. https://doi.org/10.1108/MIP-10-2014-0196.

Iglesias, O., and N. Ind. 2016. How to be a brand with a conscience. In Brands with a conscience: How to build a successful and responsible brand, ed. N. Ind and S. Horlings, 203-211. London: Kogan Page.

Iglesias, O., P. Landgraf, N. Ind, S. Markovic, and N. Koporcic. 2020a. Corporate brand identity co-creation in Business-to-business contexts. Industrial Marketing Management 85: 32-43.

Iglesias, O., S. Markovic, J. Singh, and M. Bagherzadeh Niri. 2020 b. Co-creation: A key link between corporate social responsibility, customer trust, and customer loyalty. Journal of Business Ethics 163 (1): 151-166.

Iglesias, O., N. Ind, and M. Schultz. 2020c. History matters: The role of history in corporate brand strategy. Business Horizons 63 (1): 51-60. https://doi.org/10.1016/j.bushor.2019.09.005.

Ind, N. 1997. The corporate brand. London: Palgrave MacMillan.

Ind, N. 2007. Living the brand. How to transform every member of your organization into a brand champion. London: Kogan Page Publishers.

Ind, N., and I. Ryder. 2011. Conscientious brands editorial. Journal of Brand Management 18 (9): 635-638.

Ind, N., O. Iglesias, and M. Schultz. 2013. Building brands together: Emergence and outcomes of co-creation. California Management Review 55 (3): 5-26.

Ind, N., and S. Horlings. 2016. Brands with a conscience: How to build a successful and responsible brand. London: Kogan Page.

Ind, N. 2016. Unilever and the green bond. In Brands with a conscience: How to build a successful and responsible brand, ed. N. Ind and S. Horlings, 138-139. London: Kogan Page.

Ind, N., O. Iglesias, and S. Markovic. 2017. The co-creation continuum: From tactical market research tool to strategic collaborative innovation method. Journal of Brand Management 24 (4): 310-321.

Jacoby, J., R.W. Chestnut, and W. Silberman. 1977. Consumer use and comprehension of nutrition information. Journal of Consumer Research 4 (2): 119-128.

Jensen, M.C., and W.H. Meckling. 1976. Theory of the firm: managerial behavior, agency costs and ownership structure. Journal of Financial Economics 3 (4): 305-360.

Joyner, B.E., and D. Payne. 2002. Evolution and implementation: A study of values, business ethics and corporate social responsibility. Journal of Business Ethics 41 (4): 297-311. 
Jurgens, M., P. Berthon, L. Papania, and H.A. Shabbir. 2010. Stakeholder theory and practice in Europe and North America: the key to success lies in a marketing approach. Industrial Marketing Management 39 (5): 769-775.

Kapferer, J.N. 2012. The new strategic brand management: Advanced insights and strategic thinking. London: Kogan Page.

Kazadi, K., A. Lievens, and D. Mahr. 2015. Stakeholder co-creation during the innovation process: Identifying capabilities for knowledge creation among multiple stakeholders. Journal of Business Research 69 (2): 525-540.

Keller, K.L. 1993. Conceptualizing, measuring, and managing customer-based brand equity. Journal of Marketing 57 (1): 1-22.

Kennedy, E., and F. Guzman. 2017. When perceived ability to influence plays a role: brand co-creation in Web 2.0. Journal of Product and Brand Management 26 (4): 342-350.

Kim, S., M.J. Karlesky, C.G. Myers, and T. Schifeling. 2016 Why companies are becoming B corporations. Harvard Business Review. https://hbr.org/2016/06/why-companies-are-becoming-b-corpo rations.

Kitchin, T. 2003. Corporate responsibility: A brand extension. Journal of Brand Management 10 (4/5): 312-326.

Knox, S., and S. Maklan. 2004. Corporate social responsibility: Moving beyond investment towards measuring outcomes. European Management Journal 22 (5): 508-516.

Koporcic, N., and A. Halinen. 2018. Interactive network branding: Creating corporate identity and reputation through interpersonal interaction. IMP Journal 12 (2): 392-408.

Kornberger, M. 2010. Brand society: How brands transform management and lifestyle. Cambridge: Cambridge University Press.

Kornum, N., R. Gyrd-Jones, N. Al Zagir, and K.A. Brandis. 2017. Interplay between intended brand identity and identities in a Nike related brand community: Co-existing synergies and tensions in a nested system. Journal of Business Research 70: 432-440.

Kristal, S., C. Baumgarth, and J. Henseler. 2020. Performative corporate brand identity in industrial markets: The case of German prosthetics manufacturer Ottobock. Journal of Business Research 114: 240-253.

Lee, E.M., S.Y. Park, M.I. Rapert, and C.L. Newman. 2012. Does perceived consumer fit matter in corporate social responsibility issues? Journal of Business Research 65 (11): 1558-1564.

Levy, S.J. 1959. Symbols for sale. Harvard Business Review 37 (4): 117-124.

Libert, B., Y. Wind, and M. Beck Fenley. 2015. What apple, lending club, and AirBnB know about collaborating with customers. Harvard Business Review. http://hbr.org/2015/07/what-apple -lending-club-and-airbnb-know-about-collaborating-with-custo mers.

Lodish, L.M., and C.F. Mela. 2007. If brands are built over years why are they managed over quarters? Harvard Business Review 85: $104-112$.

Lyon, T.P., M.A. Delmas, J.W. Maxwell, P. Bansal, M. ChiroleuAssouline, P. Crifo, R. Durand, J.P. Gond, A. King, M. Lenox, and M. Toffel. 2018. CSR needs CPR: Corporate sustainability and politics. California Management Review 60 (4): 5-24.

Mäläskä, M., S. Saraniemi, and J. Tähtinen. 2011. Network actors' participation in B2B SME branding. Industrial Marketing Management 40 (7): 1144-1152.

Maon, F., V. Swaen, and A. Lindgreen. 2017. One vision, different paths: An investigation of corporate social responsibility initiatives in Europe. Journal of Business Ethics 143 (2): 405-422.

Mason, C., and J. Simmons. 2014. Embedding corporate social responsibility in corporate governance: A stakeholder systems approach. Journal of Business Ethics 119: 77-86.

Maxfield, S. 2008. Reconciling corporate citizenship and competitive strategy: Insights from economic theory. Journal of Business Ethics 80 (2): 367-377.
Mazutis, D.D., and N. Slawinski. 2015. Reconnecting business and society: Perceptions of authenticity in corporate social responsibility. Journal of Business Ethics 131 (1): 137-150.

Merz, M.A., Y. He, and S.L. Vargo. 2009. The evolving brand logic: A service dominant logic perspective. Journal of the Academy of Marketing Science 37: 328-344.

Michel, G. 2017. From brand identity to polysemous brands: Commentary on "Performing identities: Processes of brand and stakeholder identity co-construction". Journal of Business Research 70: 453-455.

Mingione, M., and L. Leoni. 2019. Blurring B2C and B2B boundaries: Corporate brand value co-creation in B2B2C markets. Journal of Marketing Management. https://doi. org/10.1080/0267257X.2019.1694566.

Morrison, S., and F.G. Crane. 2007. Building the service brand by creating and managing an emotional brand experience. Journal of Brand Management 14 (5): 410-421.

Muniz, A.M., and T.C. O'Guinn. 2001. Brand community. Journal of Consumer Research 27 (March): 412-432.

Park, C.W., B.J. Jaworski, and D.J. Maclnnis. 1986. Strategic brand concept-image management. Journal of Marketing 50 (4): 135-145. https://doi.org/10.2307/1251291.

Pope, S., and A. Wæraas. 2016. CSR-washing is rare: A conceptual framework, literature review, and critique. Journal of Business Ethics 137 (1): 173-193.

Ramaswamy, V., and K. Ozcan. 2014. The co-creation paradigm. Stanford: Stanford University Press.

Rindell, A., G. Svensson, T. Mysen, A. Billström, and K. Wilén. 2011. Towards a conceptual foundation of 'conscientious corporate brands'. Journal of Brand Management 18 (9): 709-719.

Roper, S., and G. Davies. 2007. The corporate brand: Dealing with multiple stakeholders. Journal of Marketing Management 23 (1-2): 75-90.

Shaw, D., and E. Shiu. 2002. The role of ethical obligation and selfidentity in ethical consumer choice. International Journal of Consumer Studies 26 (2): 109-116.

Skudiene, V., and V. Auruskeviciene. 2012. The contribution of corporate social responsibility to internal employee motivation. Baltic Journal of Management 7 (1): 49-67.

Smith, N.C., and D. Rönnegard. 2016. Shareholder primacy, corporate social responsibility, and the role of business schools. Journal of Business Ethics 134 (3): 463-478.

Stern, B.B. 2006. What does brand mean? Historical-analysis method and construct definition. Journal of the Academy of Marketing Science 34 (2): 216-223. https://doi.org/10.1177/0092070305 284991.

Temple-West P. 2020. Has the IPO market suddenly embraced sustainability? Financial Times. 15 July 2020. https://www.ft.com/ content/4ca680ef-f087-4c4e-a6f3-e7e6fe53139f.

Törmälä, M., and R.I. Gyrd-Jones. 2017. Development of new B2B venture corporate brand identity: A narrative performance approach. Industrial Marketing Management 65: 76-85.

Urde, M., and S.A.B. Greyser. 2007. Corporate brands with a heritage. Journal of Brand Management 15 (1): 4-19.

Vallaster, C., and S. von Wallpach. 2013. An online discursive inquiry into the social dynamics of multi-stakeholder brand meaning co-creation. Journal of Business Research 66 (9): 1505-1515.

Van Rekom, J., G. Berens, and M. Van Halderen. 2013. Corporate social responsibility: Playing to win, or playing not to lose? Doing good by increasing the social benefits of a company's core activities. Journal of Brand Management 20 (9): 800-814.

von Wallpach, S., B. Voyer, M. Kastanakis, and H. Mühlbacher. 2017a. Co-creating stakeholder and brand identities: Introduction to the special section. Journal of Business Research 70: 395-398. 
von Wallpach, S., A. Hemetsberger, and P. Espersen. 2017b. Performing identities: Processes of brand and stakeholder identity coconstruction. Journal of Business Research 70: 443-452.

Walsh, G., and S.E. Beatty. 2007. Customer-based corporate reputation of a service firm: Scale development and validation. Journal of the Academy of Marketing Science 35 (1): 127-143.

Welcker, J.W. 1949. The community relations problem of industrial companies. Harvard Business Review 49 (6): 771-780.

Yan, J. 2016. Dilmah tea: Business is a matter of human service. In Brands with a conscience: How to build a successful and responsible brand, ed. N. Ind and S. Horlings, 14-26. London: Kogan Page.

Publisher's Note Springer Nature remains neutral with regard to jurisdictional claims in published maps and institutional affiliations.
Oriol Iglesias is an Associate Professor and Head of the Marketing Department at Universitat Ramon Llull, ESADE Business School. His research is focused on corporate brand management, co-creation, brand ethics and conscientious brands.

Nicholas Ind is a Professor at Kristiania University College in Norway and a Visiting Professor at ESADE and Edinburgh Napier University. His research is focused on co-creation, corporate brand management and conscientious brands. 